\title{
Mycobacterium leprae isolates from different sources have identical sequences of the spacer region between the 165 and 235 ribosomal RNA genes
}

\author{
Madeleine Y. L. de Wit and Paul R. Klatser \\ Author for correspondence: Madeleine Y. L. de Wit. Tel: +31 205665441. Fax: + 31206971841.
}

Royal Tropical Institute, Department of Biomedical Research, Meibergdreef 39, 1105 AZ Amsterdam, The Netherlands

\begin{abstract}
To test for genotypic variations between different isolates of Mycobacterium leprae, the causative agent of leprosy, the 282 bp spacer region between the $16 S$ and 235 rRNA genes was amplified using PCR, and submitted to singlestrand conformation polymorphism (SSCP) analysis. The procedure was optimized using four modified spacer fragments, containing mutations at one, three, four and six positions, respectively. Seventy-five $M$. leprae isolates from different sources, including isolates from leprosy patients, healthy individuals, armadillos and mouse footpads were identical in the SSCP analysis. DNA sequencing and restriction enzyme analysis performed on four and 40 samples, respectively, confirmed the results obtained with SSCP analysis.
\end{abstract}

Keywords: Mycobacterium leprae, 16S/23S rRNA spacer, single-strand conformation polymorphism

\section{INTRODUCTION}

Leprosy, caused by Mycobacterium leprae, is still a major health problem in many developing countries. Unfortunately it is very difficult to identify sources of infection because of the very long incubation time (Fine, 1982 ) and because $M$. leprae strains from different sources cannot be differentiated. Strain differentiation, as carried out for other mycobacteria, by phenotypic and chemotaxonomic features failed for $M$. leprae because of its inability to grow in vitro. Previous studies (Clark -Curtiss \& Walsh, 1989; Williams et al., 1990) used methods that require large amounts of purified bacteria, cultured through passage in the nine-banded armadillo (Dasypus novemcinctus Linn.). We chose a methodology which does not require large amounts of purified bacteria and is directly applicable to patient samples: $M$. leprae DNA was amplified using PCR and the resulting DNA fragments were analysed by single-strand conformation polymorphism (SSCP) analysis for possible differences (Orita et al., 1989a). The $16 \mathrm{~S} / 23 \mathrm{~S}$ ribosomal spacer region was chosen because it was found to be variable in other bacteria (Barry et al., 1991; McLaughlin et al., 1993; Matar et al., 1993; Gürtler, 1993).

Abbreviation: SSCP, single-strand conformation polymorphism.

\section{METHODS}

M. leprae samples. Seventy-five $M$. leprae samples were collected; 30 samples, directly taken as skin biopsy specimens (17) or as nasal swab specimens (13), came from multibacillary leprosy patients. Of these patients, two resided in Africa, 10 in Europe as immigrants from South-America and 18 in Asia. Twenty-three samples (nasal swab specimens) were collected from healthy individuals from Asia, who were found to carry $M$. leprae in their noses (Klatser et al., 1993; de Wit et al., 1993), but had not been diagnosed as leprosy patients. Fourteen isolates originated from armadillos: three of them were naturally infected, and 11 were experimentally infected with bacteria from multibacillary leprosy patients. Of these patients, seven were from Asia, two from Africa and two from North-America, and the bacteria had been grown for one, two or three passages in armadillos. Eight isolates originated from footpads of nude mice: one of which had been inoculated with $M$. leprae from a naturally infected Mangabey monkey from Africa and seven with bacteria from multibacillary patients from Africa. Of this latter group, six isolates had been cultured in armadillos and one in a nude mouse before inoculation into the mouse footpad.

Patients had been classified as multibacillary, when the bacterial index $(\mathrm{BI})$ was $>0$, based on the enumeration of acid-fast bacteria of skin slit smears (Ridley, 1977).

Purified chromosomal $M$. leprae DNA was kindly supplied by Dr M. J. Colston as part of the UNDP/World Bank/WHO Special Programme for Research and Training in Tropical Diseases. This DNA served as reference in all experiments.

Control samples. To confirm the specificity of the PCR, DNA 
from human placenta, a non-infected armadillo, a mouse, $M$. bovis BCG, $M$. intracellulare, $M$. fortuitum, $M$. kansasii, $M$. scrofulaceum, $M$. gordonae, $M$. vaccae and from an armadilloderived mycobacterium (ADM) were used. The origin of the mycobacterial strains was described by Hartskeerl et al. (1989).

Preparation of samples for PCR. Skin biopsy and nasal swab specimens were incubated for $18 \mathrm{~h}$ at $60^{\circ} \mathrm{C}$ in $100 \mu \mathrm{l} 10 \mathrm{rnM}$ Tris $/ \mathrm{HCl}$, pH 8.0 , containing $1 \mathrm{mg}^{2}$ proteinase $\mathrm{K} \mathrm{ml}^{-1}$ and $0 \cdot 05 \%(\mathrm{v} / \mathrm{v})$ Tween 20. M. leprae bacteria were isolated from the liver (six), spleen (five) and leproma (three) from infected armadillos (Rodde et al., 1992). Chromosomal DNA was extracted from the bacteria, as described previously (Hartskeerl et al., 1989). Mouse footpads were incubated for $18 \mathrm{~h}$ at $37^{\circ} \mathrm{C}$ in $500 \mu \mathrm{l} 10 \mathrm{mM}$ Tris $/ \mathrm{HCl}, \mathrm{pH} 8 \cdot 0$, containing $10 \mathrm{mg}$ collagenase $\mathrm{A} \mathrm{ml}^{-1}$ (Boehringer Mannheim). The skeleton was removed from the resulting tissue suspension, which was then incubated for $18 \mathrm{~h}$ at $60^{\circ} \mathrm{C}$ with proteinase $\mathrm{K} /$ Tween 20 at final concentrations of $1 \mathrm{mg} \mathrm{ml}^{-1}$ and $0.05 \%(\mathrm{v} / \mathrm{v})$, respectively.

PCR. Amplification of the $16 \mathrm{~S} / 23 \mathrm{~S}$ ribosomal spacer region was performed by two PCR runs using nested sets of primers, designed according to the sequence determined by Liesack $e t$ al. $(1990 \mathrm{a}, \mathrm{b})$. The first set of primers was from a conserved region of the 16S rRNA gene (position 1512-1529) and from an $M$. leprae-specific region of the 23S rRNA gene (position 747-768). These primers generated a 1089 bp fragment, which was used as template for the second PCR, using primers from positions $1531-1548$ of the $16 \mathrm{~S}$, and $1-18$ of the $23 \mathrm{~S}$ rRNA gene, respectively. The final product was a $318 \mathrm{bp}$ fragment containing the complete 282 bp spacer region.

Both PCR runs were performed in reaction mixtures containing $10 \mathrm{mM}$ Tris/ $\mathrm{HCl}, \quad \mathrm{pH} 9.6, \quad 7.5 \mathrm{mM} \mathrm{MgSO}_{4}, \quad 50 \mathrm{mM} \mathrm{NaCl}$, $0.01 \%$ (w/v) gelatin, $1 \mathrm{mM}$ each of the deoxynucleotides dATP, dCTP, dGTP and dTTP, $50 \mathrm{pmol}$ of each primer, $10 \%(\mathrm{v} / \mathrm{v})$ DMSO and $2.5 \mathrm{U}$ Taq DNA polymerase (Perkin Elmer). To avoid amplification of contaminating DNA samples, the PCR reaction mixtures were prepared in a DNA-free area separate from template preparation and amplification. Templates were added with positive displacement pipettes to further decrease the risk of carry-over contamination.

Because SSCP analysis requires DNA fragments with a high degree of purity, the PCR profile for both runs was performed according to the 'touchdown'-principle (Don et al., 1991). The first 10 cycles were performed with an annealing temperature of $10^{\circ} \mathrm{C}$ above the melting temperature $\left(T_{\mathrm{m}}\right)$ of the primers; the annealing temperature was then decreased by $1{ }^{\circ} \mathrm{C}$ every second cycle to the $T_{m}$ of the primers, $66^{\circ} \mathrm{C}$ for PCR- 1 and $55^{\circ} \mathrm{C}$ for PCR-2. Then 10 additional cycles were performed at this temperature, giving a total of 40 cycles.

Different amounts of template DNA were used for the first amplification and the products were separated by electrophoresis on a $2 \%(\mathrm{w} / \mathrm{v})$ agarose gel and visualized by ethidium bromide staining. Samples giving a distinct 1089 bp fragment similar in intensity to the amplification product obtained from $250 \mathrm{fg}$ of the reference DNA were diluted 1:10000 and used for the second PCR. The $318 \mathrm{bp}$ fragments were isolated from $2 \%$ agarose gels, using the GlassMax DNA Isolation System (Life Technologies) and dissolved in $50 \mu$ l distilled water. The purity of the $318 \mathrm{bp}$ fragments was checked by electrophoresis of $10 \mu \mathrm{l}$ of the GlassMax eluate on a $6 \%(\mathrm{w} / \mathrm{v})$ polyacrylamide gel in $90 \mathrm{mM}$ Tris/acetate buffer, $\mathrm{pH} 8.0$, containing $2 \mathrm{mM}$ EDTA (TAE). DNA in the gels was visualized by a Silver Stain (BioRad).

Construction of the modified 318 bp fragments. To determine the best conditions for the SSCP procedure, we constructed four modified 318 bp fragments by PCR mutagenesis using four primers for each modification (Higuchi, 1990). The $1089 \mathrm{bp}$ fragment amplified from $M$. leprae reference DNA, served as target for the mutagenesis. All modifications were chosen arbitrarily, both with respect to their position in the spacer region and to the number of nucleotides involved. All modifications introduced a restriction site into the 282 bp sequence of the spacer region (numbering as published by Liesack et al. (1991)): a 1 bp change at position 144 introduced a HaelII site (GGCT to GGCC); a change of $3 \mathrm{bp}$ at position 220, 222 and 223 resulted in a Pvul site (CGTTGT to CG $\underline{A T C G}$ ); 4 bp altered at position 158-161 resulted in another HaellI site (TTTG to GGCC) and finally a mutation of $6 \mathrm{bp}$ at position 82-87 introduced an EcoRI site (TGCGCA to GAATTC).

The non-modified fragment and the four mutated fragments were cloned using the TA-vector pCRII and Escherichia coli Inv $\alpha F^{\prime}$ competent cells (Invitrogen). Digestion with the siterespective restriction enzymes confirmed the modifications of the cloned fragments.

SSCP. The conditions for SSCP were optimized using the $318 \mathrm{bp}$ fragments amplified from the five recombinant clones. Five microlitres denaturing agent, $20 \mathrm{mM} \mathrm{NaOH}$ in dimethylformamide (DMF), was added to $5 \mu$ l of sample, followed by $10 \mathrm{~min}$ incubation at $100^{\circ} \mathrm{C}$ and quenching on ice. Then $5 \times$ sample loading buffer, either $5 \times$ TAE, containing $40 \%(\mathrm{w} / \mathrm{v})$ sucrose, $0.25 \%(\mathrm{w} / \mathrm{v})$ bromophenol blue and $0.25 \%(\mathrm{w} / \mathrm{v})$ xylene cyanol, or the same solution with the addition of $50 \%$ (v/v) glycerol was added. Samples were applied to either a $6 \%$ $(\mathrm{w} / \mathrm{v})$ polyacrylamide or a Hydrolink-Mutation Detection Enhancement (MDE) gel (AT Biochem, Malvern, Pennsylvania, USA). Dimensions of both types of matrices were: $150 \times 120 \times 1 \mathrm{~mm}$. Electrophoresis was performed in TAE, at a constant voltage of $200 \mathrm{~V}$ for $6 \mathrm{~h}$ at room temperature, when $6 \%(\mathrm{w} / \mathrm{v})$ polyacrylamide gels were used. MDE gels were run at a constant voltage of $200 \mathrm{~V}$ for $20 \mathrm{~h}$ at room temperature. No special measures were taken to achieve a uniform gel temperature. DNA on both types of gel was visualized by a Silver Stain (Bio-Rad).

The $318 \mathrm{bp}$ fragments of the $M$. leprae isolates were denatured by the method described above. Sample loading buffer without glycerol was added and samples were subsequently applied onto an MDE gel. Electrophoresis and detection of DNA was performed as described above.

Restriction enzyme analysis and DNA sequencing. As additional tests to monitor for variations within the sequence of the spacer region, restriction enzyme analysis and DNA sequencing were performed on a number of $318 \mathrm{bp}$ fragments. The restriction enzymes were selected on the basis of the known sequence of the spacer region (Liesack et al., 1991). To monitor for mutations that resulted in disappearance of known restriction sites, we selected 11 enzymes having recognition sites in the sequence of the spacer region, i.e. AvaII, AviII, DdeI, DraII, FokI, HhaI, HpaII, MboII, NspII, SauI and Sau96I. To monitor for mutations that resulted in the generation of new restriction sites, we selected 12 enzymes not having a recognition site in that sequence, i.e. $A v a \mathrm{I}, B m y \mathrm{I}, \mathrm{E}_{c o \mathrm{RI}}, \mathrm{E}_{c o \mathrm{RV}}$, HaeII, HaeIII, HinfI, MboI, MvaI, Sau3AI, SmaI and XbaI. Using these two groups of enzymes, we tested $69(24 \%)$ nucleotides for possible mutation. A $10 \mu \mathrm{l}$ sample of the GlassMax-purified 318 bp fragment was submitted to restriction enzyme analysis. Each digestion was performed under conditions as indicated by the manufacturer for the respective enzyme. Restriction patterns were analysed by electrophoresis on a $2 \%(\mathrm{w} / \mathrm{v})$ agarose gel, containing $50 \mu \mathrm{g}$ ethidium bromide $\mathrm{ml}^{-1}$. Forty $M$. leprae 
samples were analysed : 20 from leprosy patients ( 10 skin biopsy, 10 nasal swab specimens), 12 from healthy individuals, four from armadillos and four from mouse foot pads. The samples were chosen arbitrarily from each source.

For DNA sequencing, the 318 bp fragments were cloned into the TA-vector PCRII (Invitrogen). Recombinant plasmids were isolated using Qiagen Tip 100 (Diagen). DNA sequencing was performed with an upstream and a downstream primer based on the sequence of the multiple cloning site of the vector, using the T7 sequencing kit (Pharmacia). Four $M$. leprae samples were analysed: one from a leprosy patient (nasal swab specimen), one from a healthy individual, one from an armadillo and one from a mouse footpad. From each source the sample was chosen arbitrarily.

\section{RESULTS}

\section{Amplification by PCR}

The specificity of the chosen oligonucleotide primers for amplification of the $282 \mathrm{bp} M$. leprae $16 \mathrm{~S} / 23 \mathrm{~S}$ spacer region was confirmed using template DNA from several mycobacteria, mouse, armadillo and human placenta. No amplification product was observed with $250 \mathrm{fg}$ or $1 \mathrm{ng}$ template DNA for the first PCR. The only exception was M. kansasii, which gave a 318 bp amplification product with $1 \mathrm{ng}$, but not with $250 \mathrm{fg}$ template DNA. All $75 \mathrm{M}$. leprae isolates gave a single $318 \mathrm{bp}$ fragment.

\section{SSCP analysis}

The 318 bp fragments amplified from the five in vitrogenerated recombinant clones were used to optimize the SSCP procedure. With polyacrylamide gels, 4- and 6-base changes were detectable as band shifts; addition of glycerol to the sample loading buffer also produced a band shift for the fragment with three mutations. The single mutation also became apparent as a very clear shift in

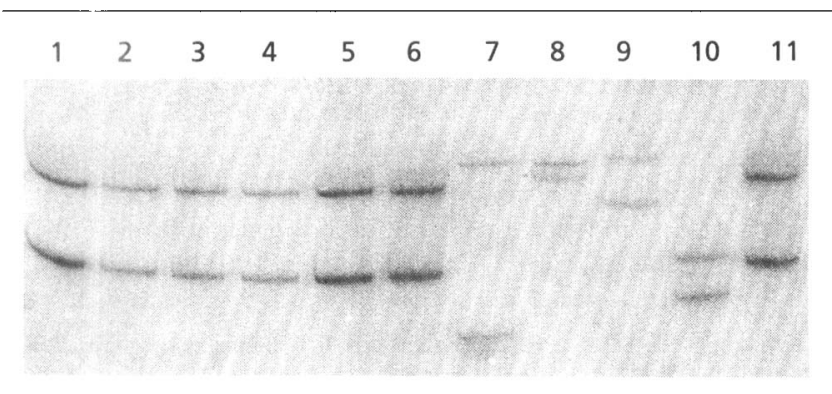

Fig. 1. SSCP analysis of $318 \mathrm{bp}$ amplification products from various $M$. leprae samples applied on a MDE gel. Lanes: 1 , isolate from an armadillo, experimentally infected with bacteria from a patient with multibacillary leprosy (MB), Asia; 2, nasal swab from a MB patient, Asia; 3, nasal swab from a healthy person, Asia; 4, skin biopsy specimen from a MB patient, Asia; 5 , isolate from a mouse footpad inoculated with bacteria from a MB patient, Africa; 6, $318 \mathrm{bp}$ from the cloned reference fragment; 7,318 bp fragment containing 1 mutation; 8,318 bp fragment containing 3 mutations; 9,318 bp fragment containing 4 mutations; 10, $318 \mathrm{bp}$ fragment containing 6 mutations; 11, WHO reference, genomic DNA. electrophoretic mobility when polyacrylamide gels were substituted by MDE gels (Fig. 1, lane 7). Glycerol did not influence the results obtained with this type of gel (results not shown). The $318 \mathrm{bp}$ fragments from all $75 \mathrm{M}$. leprae isolates were analysed on MDE gels. None of them showed a shift in the electrophoretic mobility of the two single-stranded fragments. This is illustrated for five isolates in Fig. 1 (lanes 1-5).

\section{Restriction enzyme analysis and DNA sequencing}

The occurrence of variations within the sequence of the spacer region was also investigated by restriction enzyme analysis and DNA sequencing on a number of $318 \mathrm{bp}$ fragments.

When incubated with the 11 enzymes having a recognition site in the sequence of the spacer region, the 40 investigated $M$. leprae samples revealed the same restriction patterns. The sizes of the fragments in the restriction patterns were as calculated from the positions of the recognition sites in the sequence of the spacer region as published previously (Liesack et al., 1991) (results not shown). No digestion of the $318 \mathrm{bp}$ fragments was observed when incubated with any of the 12 enzymes that did not have a recognition site in the sequence of the spacer region (results not shown).

DNA sequencing revealed that the nucleotide sequence of the $318 \mathrm{bp}$ fragments from the four investigated $M$. leprae isolates was identical to the sequence of both the reference fragment and the spacer region as published previously (Liesack et al., 1991) (results not shown).

\section{DISCUSSION}

In this paper we report the results of SSCP analysis performed on the $282 \mathrm{bp} 16 \mathrm{~S} / 23 \mathrm{~S}$ ribosomal spacer region of $75 M$. leprae isolates. The specificity for $M$. leprae of one of the oligonucleotides from within the 23S rRNA gene (positions 747-768), was determined by Liesack et al. (1991). The specificity of the PCR amplification for $M$. leprae was confirmed using various controls, including DNA from several mycobacterial species. The use of these PCR amplified fragments made it possible to use samples directly from patients and from healthy $M$. leprae-infected individuals (Klatser et al., 1993; de Wit et al., 1993). Very pure samples, essential for SSCP analysis, were obtained using high temperatures for the initial annealing steps and a two-step amplification protocol using nested primers. The results of SSCP analysis depend very much on the choice of the optimal gel running conditions for a particular DNA fragment (Orita et al., 1989a, b; Dockhorn-Dworniczak et al., 1991; Hayashi \& Yandell, 1993). Therefore, our conditions were optimized specifically for the amplified $M$. leprae spacer fragment using in vitro-constructed mutant derivatives of this fragment. Substituting Hydrolink MDE gels for polyacrylamide allowed reproducible distinction of all mutant fragments from each other and from the original sequence. These conditions would probably detect most, but not necess- 
arily all the possible base changes in the amplified fragment (Orita et al., 1989a). The effectiveness of S.SCP analysis for the high $\mathrm{G}+\mathrm{C}$ Mycobacterium DNA has been demonstrated by Telenti et al. (1993), who detected all 61 single nucleotide mutations in a set of 66 rifampicinresistant Mycobacterium tuberculosis strains.

No polymorphism could be detected among the $75 \mathrm{M}$. leprae samples which were probably representative for all the $M$. leprae strains present in the world. They were from four continents, sick and healthy infected subjects, armadillos and a monkey. Some of the samples were taken directly from the patients, others were first subcultured in armadillos and mice.

Further evidence for the lack of sequence polymorphism in the $282 \mathrm{bp}$ spacer region was obtained from the digestion of fragments with several restriction endonucleases which would have detected mutations in $24 \%$ of the nucleotides, and from the sequencing of four fragments chosen from different sources.

The apparent $100 \%$ sequence conservation of the $M$. leprae 16S/23S ribosomal spacer region seems remarkable because in other organisms this region was useful for strain differentiation (Barry et al., 1991; McLaughlin et al., 1993; Matar et al., 1993; Gürtler, 1993). It is also variable between different strains of mycobacteria and has been used for the establishment of phylogenetic relationships (Ji et al., 1994). One possible explanation for sequence conservation may be that $M$. leprae, like other slow growing mycobacteria, contains only one $r r n$ operon (Sela et al., 1989), while most other bacteria contain several, maybe allowing mutations to persist till compensating mutations neutralize deleterious effects. Other possible reasons for this conservation were put forward by ClarkCurtiss \& Walsh (1989).

The results from our study confirm the general view that all $M$. leprae isolates are very similar (Clark-Curtiss \& Walsh, 1989; Honore \& Cole, 1993; Williams et al., 1990). Some differences between $M$. leprae isolates have, however been discovered in the growth rate (Shepard \& McRae, 1971) and in the sequence of the EF-Tu gene (Silbaq \& Bercovier, 1993).

There is still a need for a method for $M$. leprae strain differentiation that would greatly help epidemiological studies, including the question of whether the different clinical manifestations of leprosy are a consequence of differences in the bacteria or the host. To determine whether genotypic variation within the species $M$. leprae does exist in other, so far undetermined parts of the genome, we will conduct further studies in which we will employ methods that give reproducible fingerprints of larger parts of the genome (Haas et al., 1993). Until results from such tests are available, we remain uncertain about the existence of different strains of $M$. leprae.

\section{ACKNOWLEDGEMENTS}

We thank Drs F. Portaels, R. J. W. Rees and T. P. Gillis for supplying us with mouse footpads and armadillo specimens.
This research was financially supported by the Netherlands Leprosy Relief Association.

\section{REFERENCES}

Barry, T., Colleran, G., Glennon, M., Dunican, L. K. \& Gannon, F. (1991). The $16 \mathrm{~S} / 23 \mathrm{~S}$ ribosomal spacer region as target for DNA probes to identify eubacteria. PCR Methods Appl 1, 51-56.

Clark-Curtiss, J. E. \& Walsh, G. P. (1989). Conservation of genomic sequences among isolates of Mycobacterium leprae. J Bacteriol 171, 4844-4851.

Dockhorn-Dworniczak, B., Dworniczak, B., Brömmelkamp, L., Bülles, J., Horst, J. \& Böcker, W. W. (1991). Non-isotopic detection of single strand conformation polymorphism: a rapid and sensitive technique in diagnosis of phenylketonuria. Nucleic Acids Res 19 2500.

Don, R. H., Cox, P. T., Wainwright, B. J., Baker, K. \& Mattick, J. S. (1991). 'Touchdown' PCR to circumvent spurious priming during gene amplification. Nucleic Acids Res 19, 4008.

Fine, P. E. M. (1982). Leprosy, the epidemiology of a slow bacterium. Epidemiol Rev 4, 161-188.

Gürtler, V. (1993). Typing of Clostridium difficile strains by PCR amplification of variable length $16 \mathrm{~S}-23 \mathrm{~S}$ rDNA spacer regions. $J$ Gen Microbiol 139, 3089-3097.

Haas, W. H., Butler, W. R., Woodley, C. L. \& Crawford, J. T. (1993). Mixed-linker polymerase chain reaction: a new method for rapid fingerprinting of isolates of the Mycobacterium tuberculosis complex. I Clin Microbiol 31, 1293-1298.

Hartskeerl, R. A., de Wit, M. Y. L. \& Klatser, P. K. (1989). Polymerase chain reaction for the detection of Mycobacterium leprae. $J$ Gen Microbiol 135, 2357-2364.

Hayashi, K. \& Yandell, D. W. (1993). How sensitive is PCR-SSCP? Human Mutation 2, 338-346.

Higuchi, R. (1990). Recombinant PCR. In PCR Protocols: A Guide to Methods and Applications, pp. 177-183. Edited by M. A. Innis, D. H. Gelfand, J. J. Sninsky \& T. J. White. New York: Academic Press.

Honore, N. \& Cole, S. T. (1993). Molecular basis of rifampicin resistance in Mycobacterium leprae. Antimicrob Agents Chemother 37, 414-418.

Ji, Y., Colston, M. J. \& Cox, R. A. (1994). Nucleotide sequence and secondary structures of precursor $16 \mathrm{~S}$ rRNA of slow-growing mycobacteria. Microbiology 140, 123-132.

Klatser, P. K., Van Beers, S., Madjid, B., Day, R. \& de Wit, M. Y. L. (1993). Detection of Mycobacterium leprae nasal carriers in populations for which leprosy is endemic. J Clin Microbiol 31, 2947-2951.

Liesack, W., Pitulle, C., Sela, S. \& Stackebrandt, E. (1990a). Nucleotide sequence of the $16 \mathrm{~S}$ rRNA from Mycobacterium leprae. Nucleic Acids Res 18, 5558.

Liesack, W., Pitulle, C. \& Stackebrandt, E. (1990b). Development of a highly specific diagnostic $23 \mathrm{~S}$ rDNA oligonucleotide probe for Mycobacterium leprae. Lett Appl Microbiol 11, 96-99.

Liesack, W., Sela, S., Bercovier, H., Pitulle, C. \& Stackebrandt, E. (1991). Complete nucleotide sequence of the Mycobacterium leprae 23S and 5S rRNA genes plus flanking regions and their potential in designing diagnostic oligonucleotide probes. FEBS Lett $\mathbf{2 8 1}$, 114-118.

McLaughlin, G. L., Howe, D. K., Biggs, D. R., Smith, A. R., Ludwinski, P., Fox, B. C., Tripathy, N., Frasch, C. E., Wenger, J. D., Carey, R. B., Hassan-King, M. \& Vodkin, H. (1993). Amplification of rDNA loci to detect and type Neisseria meningitidis and other eubacteria. Mol Cell Probes 7, 7-17. 
Matar, G. M., Swaminathan, B., Hunter, S. B., Slater, L. N. \& Welch, D. F. (1993). Polymerase chain reaction-based Restriction Fragment Length Polymorphism analysis of a fragment of the ribosomal operon from Rochalimaea species for subtyping. J Clin Microbiol 31, 1730-1734.

Orita, M., Iwahana, H., Kanazawa, H., Hayashi, K. \& Sekiya, K. (1989a). Detection of polymorphisms of human DNA by gel electrophoresis as single-strand conformation polymorphisms. Proc Natl Acad Sci US A 86, 2766-2770.

Orita, M., Suzuki, Y., Sekiya, T. \& Hayashi, K. (1989b). Rapid and sensitive detection of point mutations and DNA polymorphisms using the polymerase chain reaction. Genomics 5, 874-879.

Ridley, D. S. (1977). Skin biopsy in leprosy. Documenta Geigy 1 st edn, Pp. 13-15. Edited by Ciba-Geigy, Basel, Switzerland.

Rodde, C., Mohamed, A. A. F., Lüesse, G. \& Kazda, J. (1992). Improved method for purification of Mycobacterium leprae from armadillo tissues. Int J Lepr 60, 277-278.

Sela, S., Clark-Curtiss, J. E. \& Bercovier, H. (1989). Characterization and taxonomic implications of the rRNA genes of Mycobacterium leprae. J Bacteriol 171, 70-73.
Shepard, C. C. \& McRae, D. (1971). Hereditary characteristic that varies among isolates of Mycobacterium leprae. Infect Immun 3, 121-126.

Silbaq, F. \& Bercovier, H. (1993). Nucleotide sequence of Mycobacterium leprae elongation factor (EF-Tu) gene. Nucleic Acids Res 21, 3327.

Telenti, A., Imboden, P., Marchesi, F., Lowrie, D., Cole, S., Colston, S., Matter, L., Schopfer, K. \& Bodmer, T. (1993). Detection of rifampicin-resistance mutations in Mycobacterium tuberculosis. Lancet 341, 647-650.

Williams, D. L., Gillis, T. P. \& Portaels, F. (1990). Geographically distinct isolates of Mycobacterium leprae exhibit no genotypic diversity by restriction fragment-length polymorphism analysis. Mol Microbiol 4, 1653-1659.

de Wit, M. Y. L., Douglas, J. T., McFadden, J. \& Klatser, P. K. (1993). Polymerase chain reaction for the detection of Mycobacterium leprae in nasal swab specimens. J Clin Microbiol 31, 502-506.

Received 2 February 1994; revised 14 March 1994; accepted 17 March 1994. 